\title{
ATF1 wt Allele
}

National Cancer Institute

\section{Source}

National Cancer Institute. ATF1 wt Allele. NCI Thesaurus. Code C92178.

Human ATF1 wild-type allele is located in the vicinity of $12 \mathrm{q} 13$ and is approximately $57 \mathrm{~kb}$ in length. This allele, which encodes cyclic AMP-dependent transcription factor AT F-1 protein, plays a role in transcriptional regulation. Two translocations of this gene are associated with ang iomatoid fibrous histiocytoma and clear cell sarcoma. Translocation $t(12 ; 16)(q 13 ; p 11.2)$ with the FUS gene and $t(12 ; 22)(q 13 ; q 12)$ with the EWSR1 gene are expressed as fusion proteins. 